\title{
Laboratory Investigations into the Bearing Capacity of Straw Bales for Low-Rise Building Applications
}

\author{
Baozhu Cao, Jun Hu 1 , Yuansong Sun, and Hongxin Nie \\ School of Civil Engineering and Architecture, Hainan University, Haikou 570228, China \\ Correspondence should be addressed to Jun Hu; hj7140477@hainanu.edu.cn
}

Received 20 January 2021; Revised 22 March 2021; Accepted 26 June 2021; Published 6 July 2021

Academic Editor: Yingzi Yang

Copyright (๑) 2021 Baozhu Cao et al. This is an open access article distributed under the Creative Commons Attribution License, which permits unrestricted use, distribution, and reproduction in any medium, provided the original work is properly cited.

\begin{abstract}
Investigations were carried out to study the mechanical performance under uniaxial load of unplastered and plastered straw bales. Results from tests on 30 rice straw bales indicated nonlinear load-bearing properties with large deformations and anisotropy. Since the deformations observed did not conform to the current building code requirements, the evaluation of ultimate bearing capacity through the maximum axial vertical load was not possible. To obtain the design strength of rice straw bales in composite walls, further 21 specimens of plastered straw bales were also tested in compression. The permissible deformation of the straw bales was evaluated. It is noteworthy that the large deformability of straw bales can reduce the damage to structures after an earthquake. Consequently, the straw bale use can widely enhance the seismic performance of low-rise buildings.
\end{abstract}

\section{Introduction}

The rapid development of economy and industry in China poses a derogatory effect on the environment around us continuously. The government emphatically promotes the use of sustainable materials to construct green houses, especially in rural areas. As of today, there are more than 600 single-story straw bale houses built in North East China. Several two-story dwelling houses with light-weight steel structures and straw bales have been built as examples of modern green buildings. Human beings have a long history of utilizing straw in forms for construction of their dwelling places. Historically, they have not excluded the use of grass or reed in various forms for building construction. These materials were used because they were both readily available and reliable. European houses built of straw or reeds are now over two hundred years old. In the United States, people turned to straw houses in the 1890s with the advent of the hay/straw baler. The oldest straw bale house (built in 1903) is single-storied and still standing in Nebraska today [1]. Some books [2-4] describe the design and construction methods adopted, considering the bearing capacity and thermal properties of straw bales. They cover details of different types of straw buildings that comply with building regulation requirements. In Europe and North America, tens of thousands of people have chosen straw bales to build their homes as straw bale building is certainly becoming popular by its unique features and alternative styles.

For straw buildings to be accepted widely, more research on mechanical properties of straw bales needs to be carried out to confirm the suitability of them being adopted in dwelling houses. Over decades, many researchers have made significant effort to research on environmentally friendly materials. The cropped straw was used as fibers mixed in Earth plaster or as compressed in straw bales. Yetgin et al. [5] reported compression and tensile tests that were conducted on five different adobe mixtures. The important part of their study consisted of uniaxial compressive tests done on natural fiber mixtures. Their mechanical test results were presented in the form of stress-strain graphs and showed that compressive and tensile strength decreased with increasing fiber content. Taha et al. [6] measured the thermal conductivity of some natural plaster materials compatible for use in straw bale buildings. Such plaster materials consisted of soil, sand, and straw, with the straw being a reinforcing fiber in the plaster. In some developing countries, mud houses are still used as dwelling places. Chel and Tiwari [7] reported the potential of the annual heating and 
cooling energy saving with mud house through a case study of a vault roof mud house in India. Thus, thermal performance and embodied energy of a passive house can be evaluated. In fact, cereal straw, including wheat, barley, and rice, offers a renewable and sustainable resource stream for a variety of construction products, including compressed board panels, thatched roofing, and bales [8]. Although the use of straw bales as thermal insulation within the external envelope of building has been adequately demonstrated around the world, straw building projects are often still not regarded as straightforward in competitive solutions. This can be attributed to concerns relating to the long-term durability of the straw. Results from experimental investigations have indicated that keeping a steady humidity on equilibrium moisture content can improve its durability. The roofs of single-story straw bale buildings are supported on the straw walls, which make the strength of straw bale walls seemingly more important. A series of experiments were conducted by O'Dogherty [9] to measure the physical properties, tensile and shear strengths, and elastic moduli of the stems between nodes of wheat straw. His results showed that tensile strength was in the range of 21.2 to $31.2 \mathrm{MPa}$, and the shear strength was in the range of 4.91 to $7.26 \mathrm{MPa}$. The strength of straw bale or straw bale walls is very different from that of the straw stem, because there exist too many void spaces in large volumes. Vardy's $\mathrm{PhD}$ thesis [10] presented new models for predicting the compressive strength of plastered straw bale assemblies that are subjected to concentric and eccentric loading [11]. A constitutive model for lime-cement plaster was adapted from a stressstrain model for concrete available in the literature. Twentytwo cylinder tests on plasters typically used for straw bale construction were used to verify the constitutive model. In 2014, Palermo et al. [12] provided a more refined compression field theory for plastered straw bale walls by considering walls consisting of straw and plaster as a single entity. In another publication of Taha et al. [13], an experiment conducted with straw bale subjected to uniaxial load was described. Though the relationship of stress and strain was obtained, the stress-strain curves were described without giving the design strength for straw bales.

The research on straw bales as building materials have been mainly developed in Europe and the United States. California construction law stipulates that straw bales must be compressed to twice their initial density to be deemed to have reached failure. Simonsen from Oregon State University in the United States and Liu Kun from Northeast Forestry University in China considered the density as a control index for the bearing capacity in the straw bale performance $[14,15]$ and obtained the relationship between stress and strain under unidirectional loading to show that straw bales were materials that can sustain large deformation. On the basis of straw bales being heavily deformable materials, taking the displacement/deformation was considered as the control index. The authors, alternately, advocate that the point of failure occurs when the flat straw bales are compressed to one third of its initial height. However, since sidelong and upright straw bales exhibit a large deformation, they would be deemed to have reached failure when they have been compressed by $100 \mathrm{~mm}$. The bearing capacity at the point of failure was deemed as the ultimate compressive strength. Kim et al. [16] in their research on straw bale and plastered bale structural members conducted tests on a series of seven specimens to study the behavior of reinforced plastered straw bale composite sandwich walls. The composite system significantly improved the load-bearing capacity of straw bale and was particularly noticeable when coarse mesh and GFRP bars were used.

The aforementioned research achievements can provide better supportive references for design and construction of straw bale structures, although their application is still empirical as currently available information is limited. Undoubtedly, there may be wide differences in the properties of straw obtained from different areas or climates. This paper presents a laboratory study on the behavior of 30 straw bales and 21 plastered straw bales measuring their stiffness moduli from their respective stress-strain curves. The permissible deformation of straw bales was observed together with the contribution from the cement plaster was evaluated. The specimens for testing used rice straw harvested from Jilin province in China, and the straw bales were manufactured using a hydraulic machine.

\section{Materials and Methods}

2.1. Materials. The rice straw was first packed into bales and kept in a dry environment. The moisture content of the rice straws need to be determined and noted when the rice straw specimens were fabricated and prepared for testing. Moisture content of $20 \%$ was considered as a safe maximum for a building bale (this was the same figure for lumber) [17]. Some literatures recommend $14 \%$ as the ideal moisture content of a straw bale wall [18]. The experiments were carried out at Changchun city in Jilin province located in Northeast of China, which is characterized by a dry, but cold climate in winter. The moisture content of rice straw used in the testing was $6.1 \%$, very much lower than the permitted value. The nominal block size of common straw bales is in the range of $300 \sim 1200 \mathrm{~mm} \times 460 \mathrm{~mm} \times 360 \mathrm{~mm}$ (length, width, and height), and the density of the bales remains constant for straw bales fabricated by the same baling machine. The dimensions of specimens fabricated for the testing were $500 \mathrm{~mm} \times 400 \mathrm{~mm} \times 200 \mathrm{~mm}$ and $500 \mathrm{~mm} \times 400 \mathrm{~mm} \times 300 \mathrm{~mm}$. However, a wide variation of densities was observed, and they were $100 \mathrm{~kg} / \mathrm{m}^{3}, 200 \mathrm{~kg} / \mathrm{m}^{3}$, $300 \mathrm{~kg} / \mathrm{m}^{3}$, and $400 \mathrm{~kg} / \mathrm{m}^{3}$. It was therefore necessary to put the rice straw first into a mould as illustrated in Figure 1 and compressed using a servocontrolled hydraulic testing machine. After the straw bales were compressed to the design size, $3.4 \mathrm{~mm}$ diameter steel wire was used for baling (Figure 2). The size and density of specimens fabricated did not always conform exactly with the design. Table 1, which lists the exact details of the specimens, presents the deviation from the original plan. There were 10 groups with three specimens in each group, thereby totaling 30 straw bale specimens prepared for testing. While specimens in groups 1,2 , and $4 \sim 10$ were laid flat and tested in a horizontal 


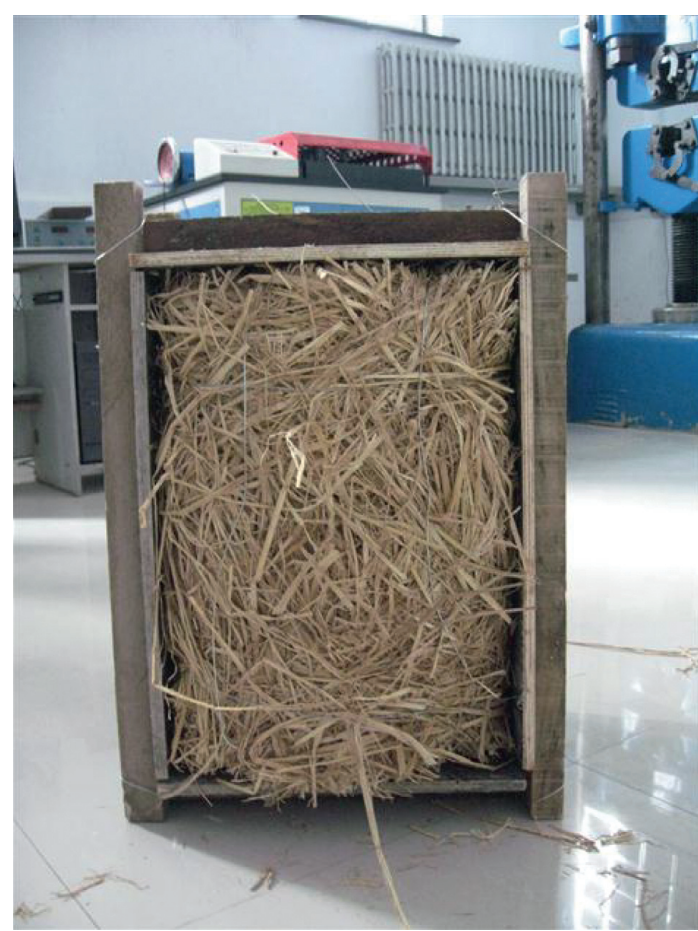

FIGURE 1: The wood mould of rice straw bale.

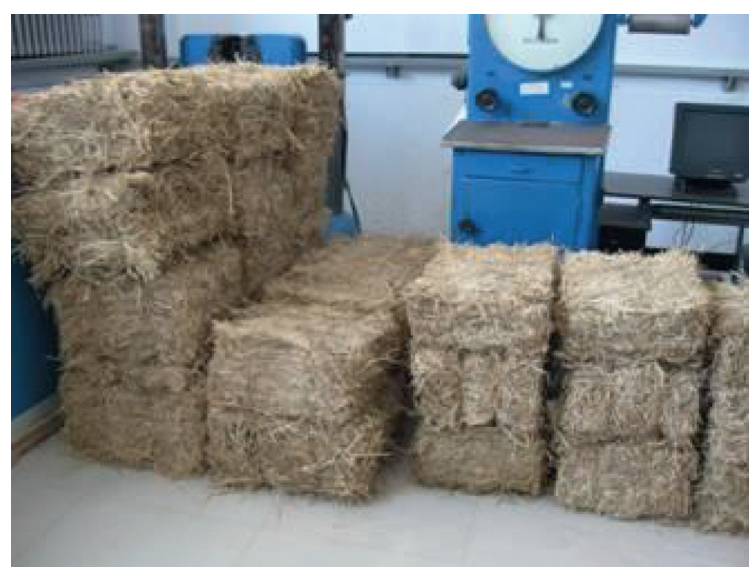

Figure 2: The rice straw specimens.

orientations, specimens in group 3 were laid on an edge and tested in a vertical orientation.

As there are cement plaster layers on both surfaces of straw bale walls in conventional construction practices, 21 specimens of straw bales were fabricated with such cement plaster layers. To represent loading conditions in practice, the straw bales were subjected to uniaxial loading. 16 specimens in group 11 16 were plastered straw bales, as shown in Figure 3(a), and three specimens in group 17 were plastered straw bales as shown in Figure 3(b). In addition, thin steel meshes were placed on specimens in group 16 . There were also three specimens in each group. While the design strengths anticipated for the three types of plaster were $5 \mathrm{MPa}, 7.5 \mathrm{MPa}$, and $10 \mathrm{MPa}$, the measured in situ strengths of the three plasters were $6.4 \mathrm{MPa}, 8.0 \mathrm{MPa}$, and 10.2 $\mathrm{MPa}$. The dimensions and densities of the plastered straw bales were designed to be the same as unplastered straw bale specimens. All specimens were placed flat in horizontal orientations for testing. The detailed parameters of the straw bales and plastered straw bales are shown in Table 2.

2.2. Methods. Since the surface of rice straws was not smooth and with the anticipation that test blocks will generate large horizontal (lateral) deformations under vertical (axial) loads, a unique method was adopted to observe the displacements (deformations) in the horizontal and vertical directions. A total of eight displacement sensors linked to a data logging computer were used to measure the horizontal and vertical displacements of straw bales. The four vertical displacement sensors responded to the vertical movement of the hydraulic testing machine's steel loading platen. Tips of the other four sensors measuring the test block's horizontal displacement were touching the stiff planar wooden laminate cards placed on the side surfaces of straw bales (Figure 4). The displacement values corresponding to the different axial loads were used to calculate the strength, rigidity modulus, and Poisson's ratio of the bale being tested. With increasing vertical uniaxial load, the test bale became denser with the consequent rapidly changing horizontal and vertical displacements. The continuous vertical uniaxial loading was stopped when the vertical displacement corresponded to $1 / 3$ of the initial dimension of the block height. The mechanical performances of the plastered straw bale specimens were probably affected by the cement plaster, particularly the ultimate strength being reached even after the cement plaster was destroyed.

\section{Experimental Program}

3.1. Test Setup. The test setup for unplastered straw bales is shown in Figure 5. This setup consisted of three $10 \mathrm{~mm}$ thick wooden plates, three $20 \mathrm{~mm}$ thick steel plates, three $120 \mathrm{~mm}$ long square-sectioned wooden beams, and $150 \mathrm{~mm}$ long square-sectioned wooden beam. The axial compressing load was provided by a hydraulic servotesting machine, whose maximum force was 60 tons. The same setup was used for plastered straw bales, except that the $150 \mathrm{~mm}$ square wooden beam was substituted by an "I" section steel beam (Figure 6).

3.2. Test Protocol. The quality and dimensions of the rice straw bales were observed, measured, and recorded prior to the application of the vertical load from the microcomputercontrolled electrohydraulic servotesting machine. The loading was applied with the loading platen movement as a control index and a rate of relative movement of $0.2 \mathrm{~mm} / \mathrm{s}$ being adopted. Concurrent with the application of the vertical load, the vertical (axial) and lateral displacement sensors were accurately monitored. The data acquisition from all sensors was timed to sample and log the data at intervals of every two seconds.

During the testing of unplastered straw bale blocks laid flat, the blocks became denser with increasing vertical load as expected. When the height of the straw bale blocks was 
TABLE 1: The parameters of straw bale specimens.

\begin{tabular}{|c|c|c|c|c|c|c|c|c|}
\hline Designation & $\begin{array}{l}\text { Length } \\
(\mathrm{mm})\end{array}$ & $\begin{array}{l}\text { Width } \\
(\mathrm{mm})\end{array}$ & $\begin{array}{l}\text { Height } \\
(\mathrm{mm})\end{array}$ & $\begin{array}{l}\text { Weight } \\
(\mathrm{kg})\end{array}$ & $\begin{array}{l}\text { Density } \\
\left(\mathrm{kgm}^{-3}\right)\end{array}$ & $\begin{array}{c}\text { Ultimate strength } \\
(\mathrm{MPa})\end{array}$ & $\begin{array}{c}\text { Elastic modulus } \\
(\mathrm{MPa})\end{array}$ & Poisson's ratio \\
\hline $1 \mathrm{~A}$ & 510 & 397 & 161 & 7.76 & 237 & 0.31 & 0.282 & 0.13 \\
\hline $1 \mathrm{~B}$ & 485 & 391 & 180 & 7.86 & 230 & 0.34 & 0.257 & 0.14 \\
\hline $1 \mathrm{C}$ & 500 & 397 & 178 & 7.90 & 222 & 0.24 & 0.179 & 0.11 \\
\hline $2 \mathrm{~A}$ & 492 & 227 & 382 & 7.88 & 184 & 0.07 & 0.531 & 0.20 \\
\hline $2 \mathrm{~B}$ & 495 & 224 & 396 & 7.94 & 181 & 0.06 & 0.293 & 0.17 \\
\hline $2 \mathrm{C}$ & 498 & 243 & 362 & 7.88 & 180 & 0.06 & 0.237 & 0.23 \\
\hline $3 \mathrm{~A}$ & 372 & 235 & 371 & 7.92 & 243 & 0.09 & 0.617 & 0.31 \\
\hline $3 B$ & 385 & 217 & 474 & 7.90 & 199 & 0.05 & 0.149 & 0.29 \\
\hline $3 \mathrm{C}$ & 386 & 219 & 474 & 277.94 & 198 & 0.05 & 0.183 & 0.26 \\
\hline $4 \mathrm{~A}$ & 501 & 401 & 124 & 3.80 & 151 & 0.22 & 0.195 & 0.11 \\
\hline $4 \mathrm{~B}$ & 507 & 407 & 120 & 3.80 & 152 & 0.09 & 0.107 & 0.35 \\
\hline $4 \mathrm{C}$ & 515 & 440 & 121 & 3.80 & 139 & 0.04 & 0.044 & 0.17 \\
\hline $5 \mathrm{~A}$ & 472 & 372 & 251 & 11.86 & 268 & 0.75 & 0.621 & 0.15 \\
\hline $5 B$ & 500 & 392 & 238 & 11.62 & 249 & 0.56 & 0.404 & 0.13 \\
\hline $5 \mathrm{C}$ & 493 & 381 & 247 & 11.56 & 249 & 0.61 & 0.281 & 0.26 \\
\hline $6 \mathrm{~A}$ & 520 & 425 & 234 & 15.88 & 307 & 0.60 & 0.445 & 0.17 \\
\hline $6 \mathrm{~B}$ & 500 & 406 & 263 & 15.90 & 298 & 0.54 & 0.366 & 0.14 \\
\hline $6 \mathrm{C}$ & 500 & 395 & 263 & 15.92 & 306 & 0.65 & 0.353 & 0.29 \\
\hline $7 \mathrm{~A}$ & 535 & 397 & 194 & 5.71 & 138 & 0.05 & 0.068 & 0.17 \\
\hline $7 \mathrm{~B}$ & 485 & 380 & 207 & 5.84 & 153 & 0.10 & 0.122 & 0.12 \\
\hline $7 \mathrm{C}$ & 527 & 398 & 203 & 5.86 & 138 & 0.05 & 0.070 & 0.11 \\
\hline $8 \mathrm{~A}$ & 527 & 450 & 288 & 11.40 & 166 & 0.16 & 0.059 & 0.20 \\
\hline $8 \mathrm{~B}$ & 492 & 380 & 294 & 12.14 & 221 & 0.37 & 0.182 & 0.35 \\
\hline $8 \mathrm{C}$ & 470 & 377 & 275 & 11.90 & 244 & 0.48 & 0.369 & 0.16 \\
\hline $9 \mathrm{~A}$ & 495 & 390 & 319 & 18.08 & 294 & 0.85 & 0.496 & 0.33 \\
\hline $9 B$ & 522 & 402 & 305 & 17.52 & 273 & 0.60 & 0.433 & 0.32 \\
\hline $9 \mathrm{C}$ & 510 & 403 & 295 & 17.74 & 292 & 0.69 & 0.697 & 0.33 \\
\hline $10 \mathrm{~A}$ & 520 & 407 & 340 & 23.96 & 333 & 1.19 & 0.565 & 0.38 \\
\hline $10 \mathrm{~B}$ & 537 & 443 & 335 & 23.92 & 299 & 0.63 & 0.452 & 0.29 \\
\hline $10 \mathrm{C}$ & 522 & 408 & 329 & 23.68 & 338 & 1.20 & 0.615 & 0.34 \\
\hline
\end{tabular}

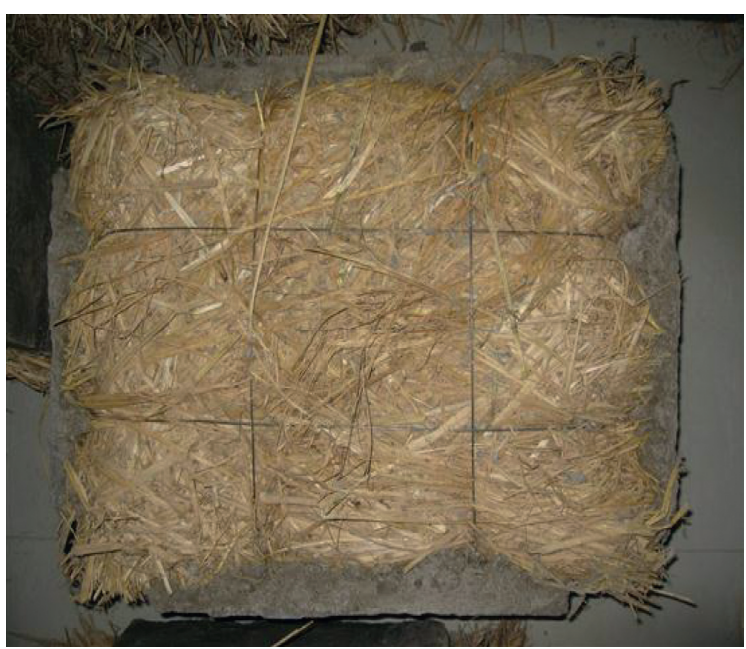

(a)

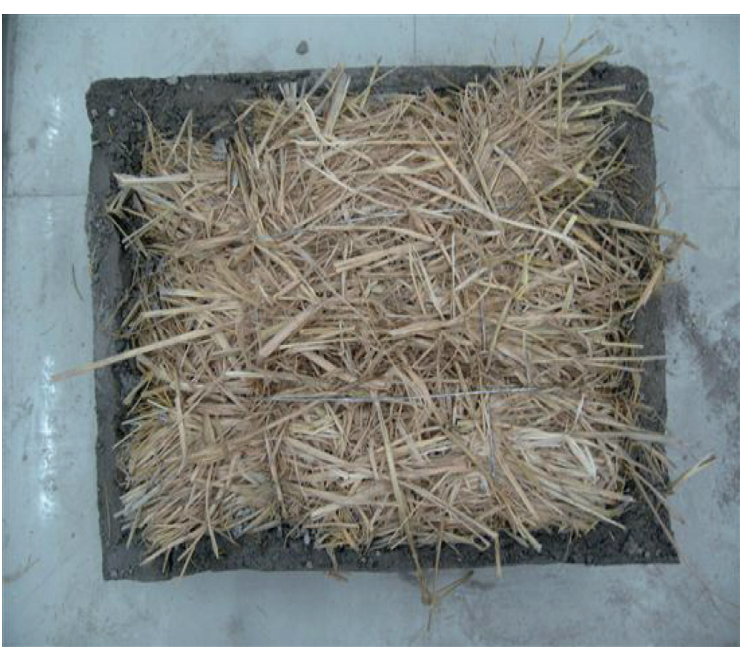

(b)

Figure 3: Plastered straw bales. (a) Straw bales with incomplete plaster (no plaster on the corners). (b) Straw bales with complete plaster.

reducing, the horizontal dimensions of the block were expanding laterally. When the vertical deformation of straw bale blocks exceeded $1 / 3$ of block's initial height, any further vertical loading was stopped.
In the case of plastered straw bales, the strength of specimens probably relied more on that of the plaster layers; therefore, the stage of the plaster failing was the criterion to stop any further loading. 
TABLE 2: The parameters of plastered straw bale specimens.

\begin{tabular}{|c|c|c|c|c|c|c|c|c|c|c|c|}
\hline \multirow[b]{2}{*}{ Designation } & \multicolumn{5}{|c|}{ Straw bales } & \multicolumn{4}{|c|}{ Plaster } & \multicolumn{2}{|c|}{ Composite bales } \\
\hline & $\begin{array}{l}\text { Length } \\
(\mathrm{mm})\end{array}$ & $\begin{array}{l}\text { Width } \\
(\mathrm{mm})\end{array}$ & $\begin{array}{l}\text { Height } \\
(\mathrm{mm})\end{array}$ & $\begin{array}{l}\text { Weight } \\
\text { (kg) }\end{array}$ & $\begin{array}{l}\text { Density } \\
\left(\mathrm{kgm}^{-3}\right)\end{array}$ & $\begin{array}{l}\text { Length } \\
(\mathrm{mm})\end{array}$ & $\begin{array}{l}\text { Width } \\
(\mathrm{mm})\end{array}$ & $\begin{array}{l}\text { Thickness } \\
(\mathrm{mm})\end{array}$ & $\begin{array}{l}\text { Strength } \\
(\mathrm{MPa})\end{array}$ & $\begin{array}{c}\text { Ultimate } \\
\text { strength } \\
(\mathrm{MPa})\end{array}$ & $\begin{array}{c}\text { Vertical } \\
\text { displacement }(\mathrm{mm})\end{array}$ \\
\hline $11 \mathrm{~A}$ & 490 & 390 & 200 & 8.10 & 212 & 250 & 230 & 5 & 8.0 & 46.5 & 3.012 \\
\hline $11 B$ & 490 & 390 & 200 & 8.12 & 212 & 250 & 230 & 5 & 8.0 & 56.0 & 3.366 \\
\hline $11 \mathrm{C}$ & 500 & 390 & 200 & 8.10 & 208 & 250 & 230 & 5 & 8.0 & 38.5 & 4.748 \\
\hline $12 \mathrm{~A}$ & 490 & 400 & 210 & 8.04 & 195 & 250 & 230 & 9 & 8.0 & 78.5 & 3.485 \\
\hline $12 \mathrm{~B}$ & 490 & 400 & 210 & 7.94 & 193 & 250 & 230 & 9 & 8.0 & 45.8 & 3.063 \\
\hline $12 \mathrm{C}$ & 490 & 400 & 200 & 8.04 & 205 & 250 & 230 & 9 & 8.0 & 40.3 & 3.079 \\
\hline $13 \mathrm{~A}$ & 500 & 400 & 200 & 8.00 & 200 & 250 & 230 & 13 & 8.0 & 83.1 & 3.588 \\
\hline $13 \mathrm{~B}$ & 490 & 400 & 200 & 8.04 & 205 & 250 & 230 & 13 & 8.0 & 85.5 & 3.503 \\
\hline $13 \mathrm{C}$ & 500 & 390 & 200 & 8.06 & 207 & 250 & 230 & 13 & 8.0 & 104.7 & 3.861 \\
\hline $14 \mathrm{~A}$ & 490 & 390 & 200 & 7.94 & 208 & 250 & 230 & 9 & 6.4 & 50.2 & 3.538 \\
\hline $14 \mathrm{~B}$ & 490 & 390 & 210 & 8.06 & 201 & 250 & 230 & 9 & 6.4 & 57.7 & 4.516 \\
\hline $14 \mathrm{C}$ & 500 & 390 & 210 & 8.02 & 196 & 250 & 230 & 9 & 6.4 & 27.9 & 3.311 \\
\hline $15 \mathrm{~A}$ & 490 & 390 & 210 & 8.10 & 202 & 250 & 230 & 9 & 10.2 & 68.0 & 2.211 \\
\hline $15 \mathrm{~B}$ & 500 & 390 & 200 & 8.00 & 205 & 250 & 230 & 9 & 10.2 & 101.0 & 3.073 \\
\hline $15 \mathrm{C}$ & 490 & 390 & 200 & 8.10 & 212 & 250 & 230 & 9 & 10.2 & 73.9 & 2.073 \\
\hline $16 \mathrm{~A}$ & 500 & 400 & 190 & 8.06 & 212 & 250 & 230 & 9 & 8.0 & 77.0 & 3.351 \\
\hline $16 \mathrm{~B}$ & 500 & 410 & 200 & 8.06 & 197 & 250 & 230 & 9 & 8.0 & 64.2 & 3.128 \\
\hline $16 \mathrm{C}$ & 490 & 400 & 210 & 8.02 & 195 & 250 & 230 & 9 & 8.0 & 64.4 & 3.222 \\
\hline $17 \mathrm{~A}$ & 500 & 400 & 200 & 8.02 & 201 & 518 & 418 & 9 & 8.0 & 107.9 & 3.338 \\
\hline $17 \mathrm{~B}$ & 500 & 400 & 200 & 8.02 & 201 & 518 & 418 & 9 & 8.0 & 80.2 & 3.282 \\
\hline $17 \mathrm{C}$ & 500 & 400 & 200 & 8.08 & 202 & 518 & 418 & 9 & 8.0 & 109.2 & 3.052 \\
\hline
\end{tabular}

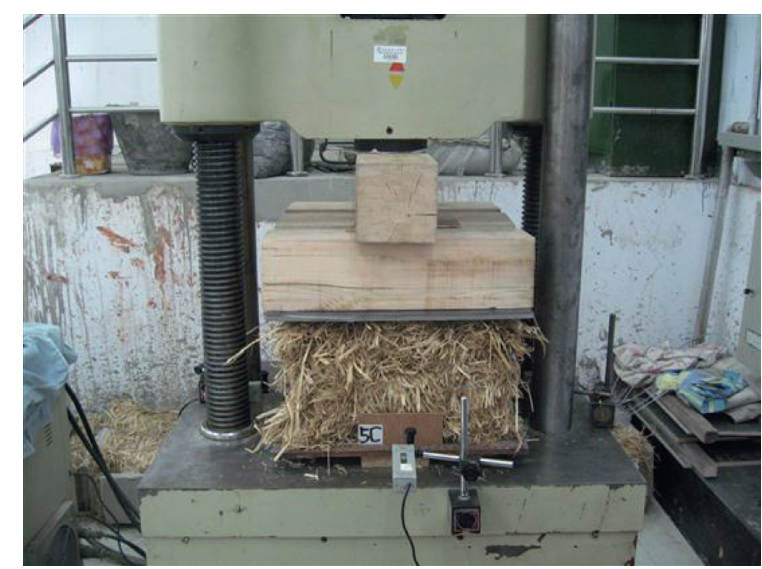

FIGURE 4: Setup and displacement sensors.

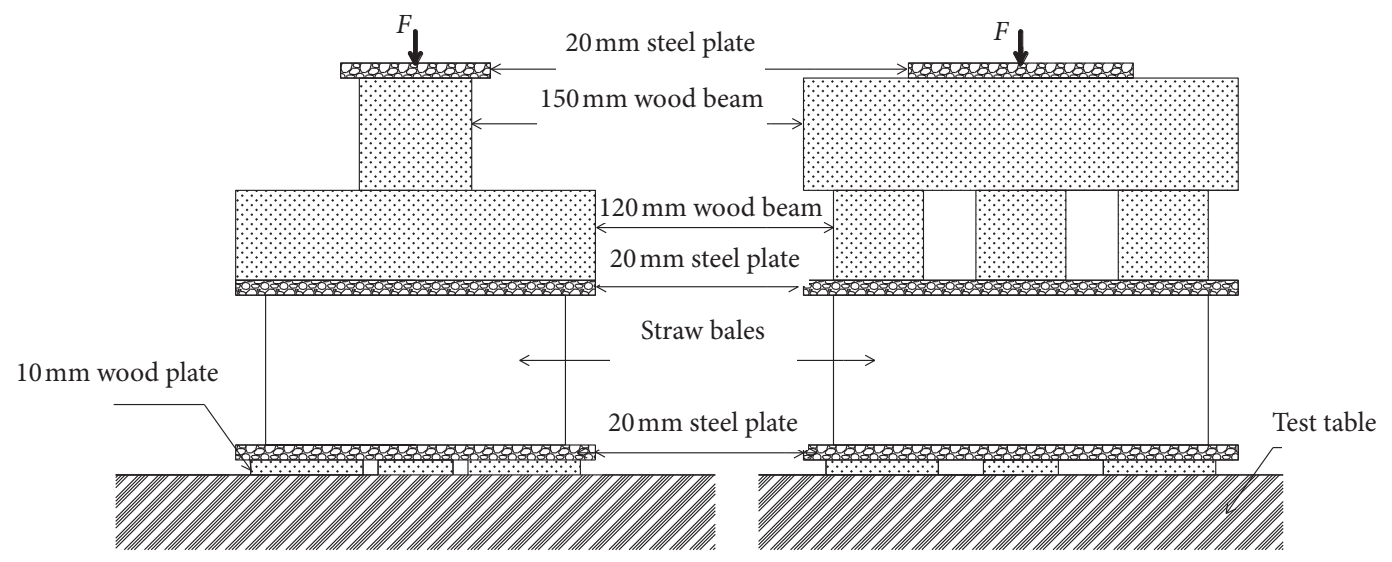

(a)

(b)

Figure 5: The experimental setup of unplastered straw bales. (a) Front elevation. (b) Side elevation. 


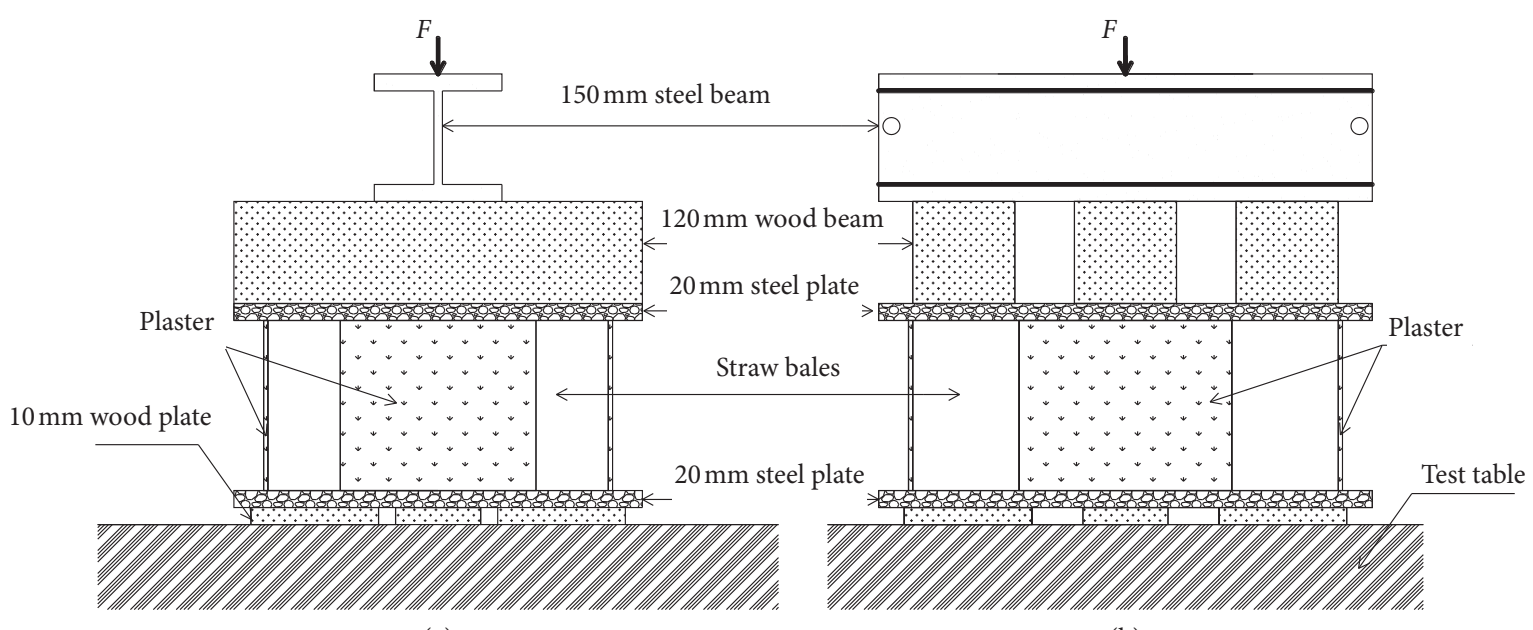

(a)

(b)

FIgURE 6: The experimental setup of plastered straw bales. (a) Front elevation. (b) Side elevation.

3.3. Test Sequence and Phenomena. Cement stucco was used for plaster construction, and cubes of plaster were tested after natural open air curing for four weeks. Cube strengths of the plaster cubes are listed in Table 2. The thickness of plaster layers on the side surfaces of straw bales were not the same. Therefore, the mean thickness of plaster on each side was adopted for analyzing.

The deformed unplastered straw bales after testing are shown in Figure 7. At this stage, the bearing load could have been increased further, but the tests were terminated as the vertical deformation had reached the controlled limit criterion. The lateral elongation in a direction along the straw stems was very small, and the deformation in other orthogonal directions was more significant. The straw bale specimens tested when the blocks were laid in a horizontal orientation gave the usually expected deformation under a vertical uniaxial load of $10 \mathrm{kN}$, but the specimens tested when the blocks were laid in a vertical orientation resulted in a larger axial deformation under a vertical load of $5 \mathrm{kN}$. The lateral deformation of straw bales laid in a vertical orientation during testing was much more significant than that observed when the blocks were laid in a horizontal orientation.

With plastered straw bale specimens, it was found that the deformation was not as expected. The vertical displacement was about $3 \sim 4 \mathrm{~mm}$ when signs of failure phenomena occurred in the plastered layers. Some such failure phenomena that were observed in the plastered specimens are shown in Figure 8. The three different examples in Figure 8 are meant to show (a) the failure observed in straw bales plastered inadequately with no mesh, (b) the failure in straw bales plastered incompletely but with fine steel mesh, and (c) the failure observed in completely plastered straw bales. From the failure types in (a) and (b), it can be deduced that the failure was caused by the fracture of plaster layers. However, similarly induced crack patterns were apparent in the failure of completely plastered straw bale specimens. Comparing the bearing capacity of the three types of plastered specimens, the bearing capacity of the completely plastered straw bales was approximately $20 \%$ greater than that with incomplete plaster. It was also noted that when a thin steel mesh was used in the straw bales with incomplete plaster, its bearing capacity improved by approximately $10 \%$.

\section{Results and Discussion}

4.1. Unplastered Straw Bales. There were 30 specimens of unplastered straw bales tested in the experimental program. Three bales (3A, 3B, and 3C) were tested when laid on an onedge orientation, and the other bales on an on-edge orientation were laid horizontal in a flat orientation. The testing results, including density, ultimate strength, elastic modulus, and Poisson's ratio, are listed in Table 1. All specimens displayed regular similarity in the relationship of load with vertical displacement. Eight representative load-displacement curves of bales with different densities are presented in Figure 9. Figure 9(a) shows that, in the case of bales with an approximate initial volume of $0.04 \mathrm{~m}^{3}$, the rate of load increase with displacement increases with increasing straw bale density. A similar observation can be deduced from Figure 9(b), where the initial volume of the straw bale was larger and approximately $0.06 \mathrm{~m}^{3}$. During this research, the unplastered straw bales displayed a nonlinear mechanical performance, making it unfeasible to establish either a bearing capacity or an elastic modulus reliably. The bearing capacity of straw bales was determined using the load sustained at a vertical displacement of $1 / 3$ of initial block height. The elastic modulus was calculated using the stressstrain curves observed for straw bales. Stress-strain curves were evaluated from the load-displacement data. Figure 10 illustrates the relationship between ultimate strength and straw bale density. The deduction was that as expected the ultimate strength increases with increasing density. Similarly, Figure 11 shows that the elastic modulus also increases with the density of the unplastered straw bales. Although the data collected from tests for these two figures were on different and separate specimens, they confirm the trends that were expected. Since the straw bale specimens were manually fabricated, it inherently embodies some deviations 


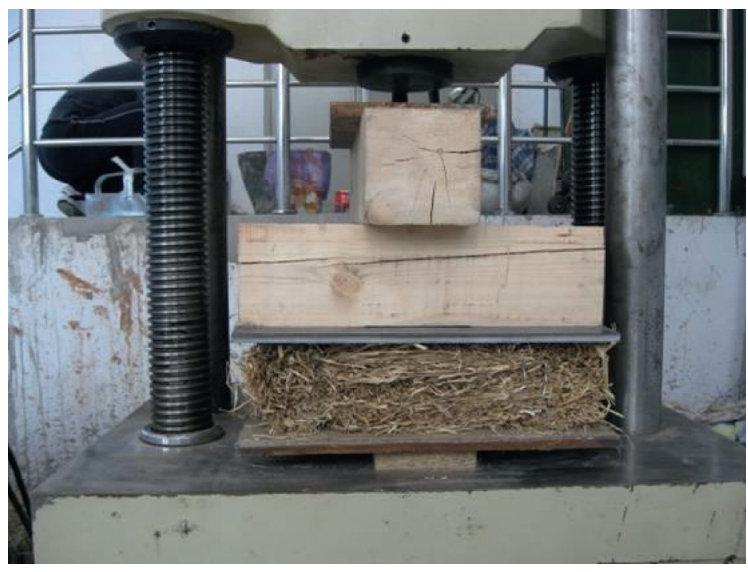

Figure 7: The large deformation of straw bale.

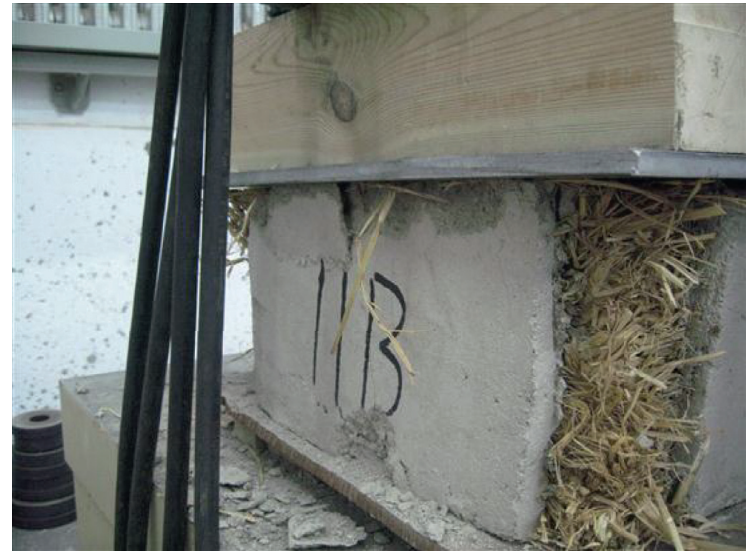

(a)

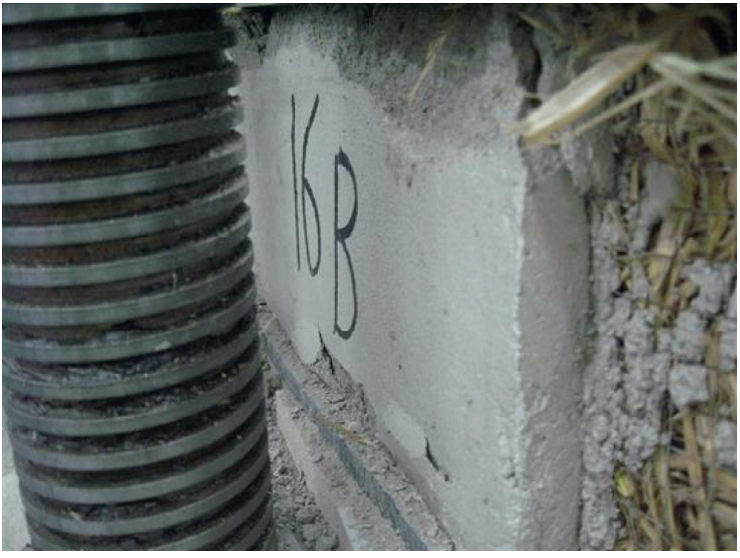

(b)

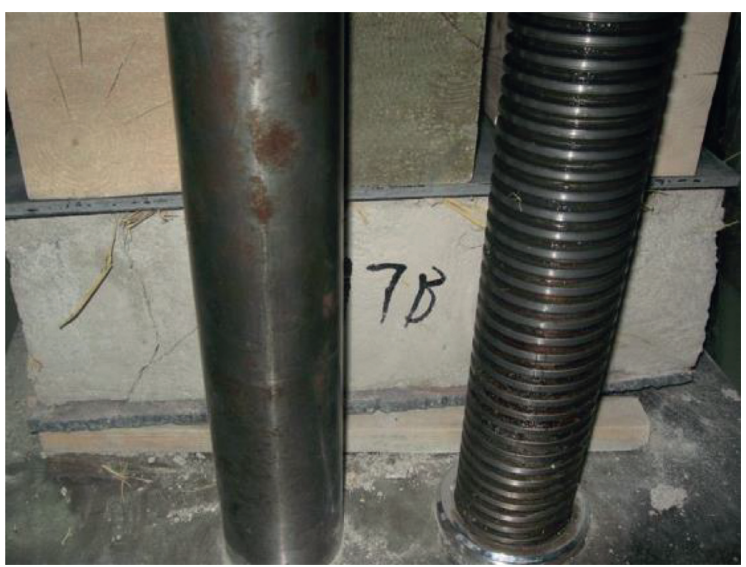

(c)

FIGURE 8: The phenomena of plastered straw bales. (a) Incompletely plastered straw bale. (b) Incompletely plastered straw bale with mesh. (c) Completely plastered straw bales.

from the design of experiment. Table 1 shows that elastic moduli of flat straw bales were extremely low and highly variable, ranging from $0.044 \mathrm{MPa}$ to $0.697 \mathrm{MPa}$. Poisson's ratio for flat bales was found to be ranging from 0.11 to 0.38 . For on-edge specimens, the straw bale modulus was found to be ranging from $0.149 \mathrm{MPa}$ to $0.617 \mathrm{MPa}$, and Poisson's ratio ranged from 0.26 to 0.31 . The authors believe that more consistent values of elastic modulus and Poisson's ratio for unplastered straw bales can be determined for building design, if the straw bales fabrication is standardized.

4.2. Plastered Straw Bales. Large displacements were observed in the tests of unplastered straw bales, but these will not occur if and when the straw bales are plastered with a 


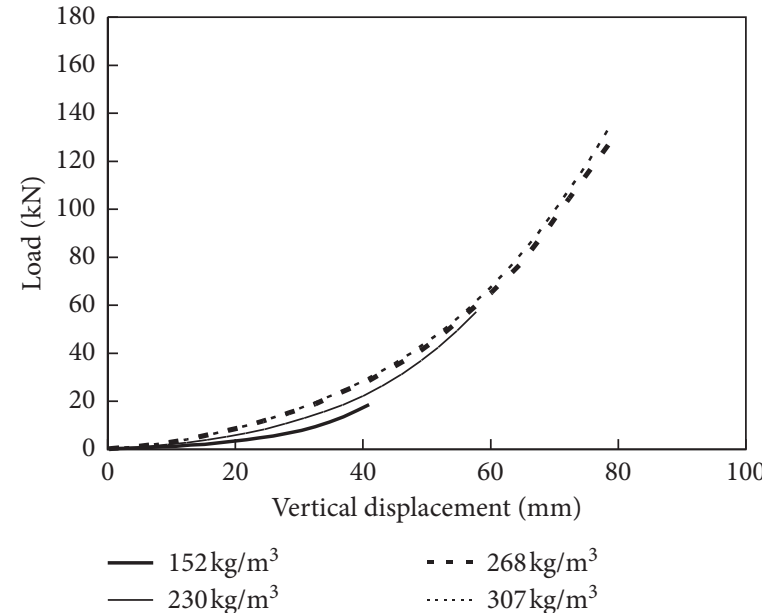

(a)

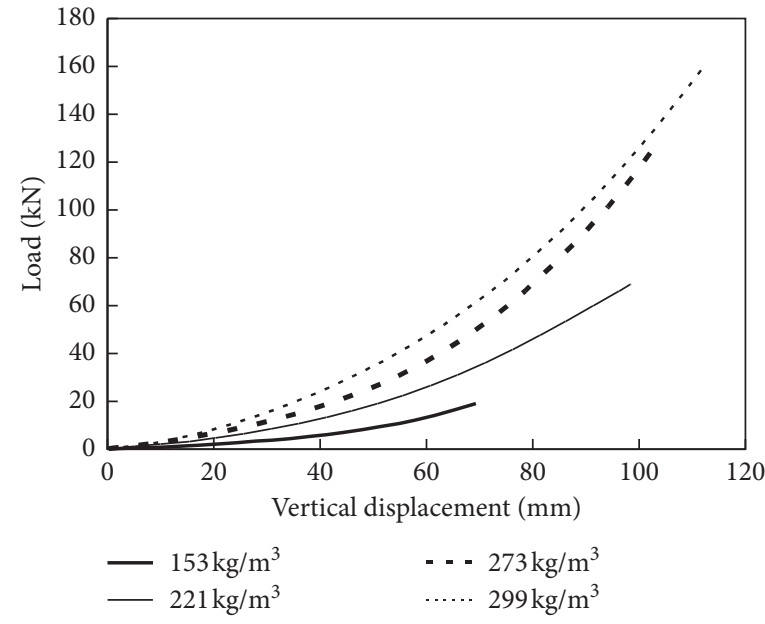

(b)

Figure 9: Load-displacement curves for the unplastering straw bales laid flat. (a) Initial volume of $0.04 \mathrm{~m}^{3}$. (b) Initial volume of $0.06 \mathrm{~m}^{3}$.

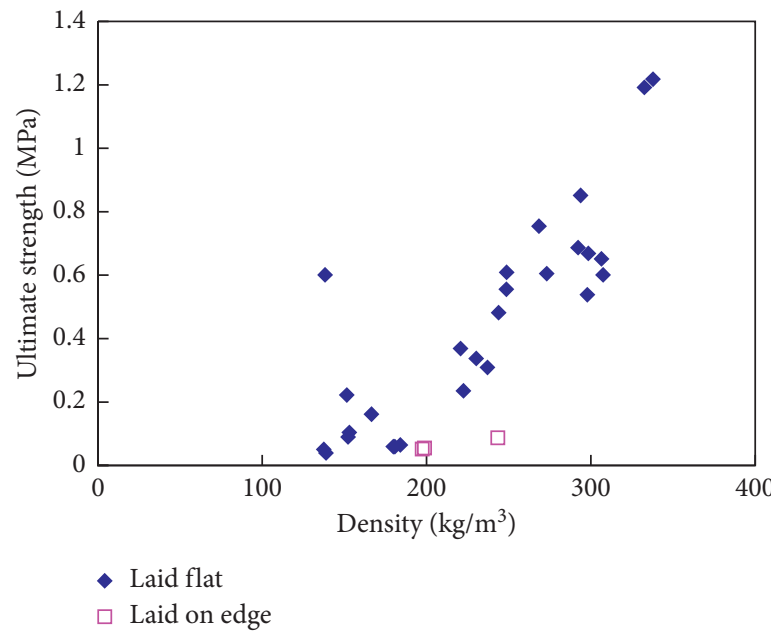

Figure 10: The relationship between the ultimate strength and density of unplastered straw bales.

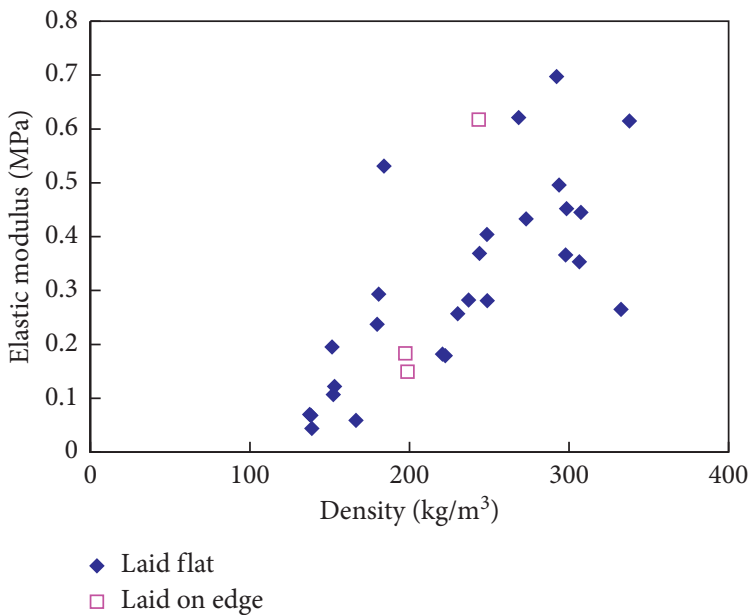

FIGURE 11: The relationship between the elastic modulus and density of unplastered straw bales. 
cement layer on the side surfaces. In fact, it is a norm that all straw bale walls of houses are covered with plaster layers, creating the effect of a composite structure. Hence, the contributory beneficial effects from plaster should be harnessed and considered in the evaluation of bearing capacity of straw bale walls. Twenty-one specimens of plastered straw bales were tested to evaluate the ultimate bearing capacity through observations of the vertical displacement and loaddisplacement relationship. The ultimate strengths of composite specimens and maximum vertical displacements are listed in Table 2, and a plot of load-displacement curves for the plastered straw bales is as shown in Figure 12. According to the curves in this figure, the mechanical characteristics show that its slope at the start of the loading is flat. After the vertical displacement exceeded $2 \mathrm{~mm}$, the slope of the curves rose gradually to become steep. The peak of the curves gives the ultimate load and corresponding displacement. Subsequently, the curves dropped with displacement. Specimen $11 \mathrm{~B}$ was an incompletely plastered straw bale (Figure $8(\mathrm{a})$ ), specimen $16 \mathrm{~B}$ was an incompletely plastered straw bale with a steel mesh (Figure 8(b)), and specimen 17B was a completely plastered straw bale (Figure 8(c)). Notably, the three completely plastered specimens gave a similar strength of 8.0 MPa. Hence, it can also be inferred that placing a steel wire mesh in the plaster can further improve the ultimate strength of specimen. A straw bale completely enclosed with plaster will improve the strength even more.

Equation (1) presents the sharing mechanism of the contributions by the straw bales and the plaster to account for the ultimate strength of the composite specimens. The ultimate bearing capacity could be expressed as

$$
F_{u}=f_{c}^{\prime} \cdot A_{c}+f_{s} \cdot A_{s}+E_{s t r} \cdot \varepsilon_{0} \cdot A_{s t r},
$$

where $F_{u}$ is the ultimate bearing load of composite specimens, $f_{c}^{\prime}$ and $A_{c}$ are the strength and bearing area of plaster, $f_{s}$ and $A_{s}$ are the strength and corresponding area of steel wire mesh section, $E_{s t r}$ and $A_{s t r}$ are the elastic modulus and bearing area of straw bales when laid flat, and $\varepsilon_{0}$ is the strain corresponding to the ultimate strength of the plaster.

4.3. Discussion and Advices. Similar mechanical compression curves were obtained for the straw bales when plotted separately based on each physical parameter (density, dimensions, and bale orientation) through the analysis of the load-displacement curve. As one would expect, on comparing the tests on plastered bales with unplastered bales, it was shown that using plaster improved the load-bearing capacity of the straw bales. The maximum vertical displacement observed for straw bales in the tests was beyond $40 \mathrm{~mm}$, whereas the cement plaster layer was destroyed at displacements no more than $5 \mathrm{~mm}$. Therefore, the bearing capacity of straw bales could be insufficient, if and when the plaster is compressed to failure. According to literature [10], the maximum strain in plaster at failure is in the order of 0.00253. If uniform deformation of plastered straw bale is achieved, the strain in the straw $\left(\varepsilon_{0}\right)$ will also be approximately 0.00253 at failure. The method adopted to determine the elastic modulus of straw bales is very important as it can

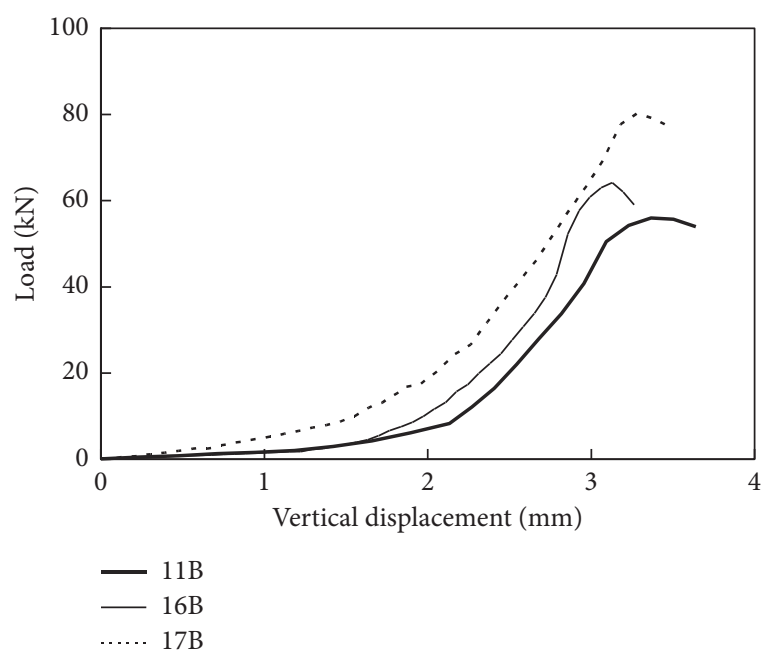

FIGURE 12: Load-displacement curves for the plastered straw bales laid flat.

affect the calculated bearing capacity considerably. The moduli of straw bales vary with different densities. Elastic modulus can be defined in at least two ways: tangent modulus or secant modulus. Here, the secant modulus at the point of plaster's yielding strain is recommended when determining the elastic modulus of the straw bales. Thus, the corresponding stress in the straw bale needs to be considered as the design bearing strength.

The material and mechanical properties of straw bales can be different and vary characteristically depending on the type and source of the straw. Testing of straw materials should be carried out before a straw structure is designed. Though straw bales can be used to construct a single-story house, it is advisable to limit its use to internal enclosure walls because of its property of being overly compressible. Alternately, if they were to be used as load-bearing walls and before plastering, the stock pile of straw bale assemblies can be exhausted by the mere load of roof. Prestressing technique can be adapted to minimize the occurrence of excessive postconstruction deformation. The characteristic large deformability of straw bales can be appropriately accommodated to improve the building performance against seismic damage during an earthquake. Straw bales therefore can be ideally placed as antiseismic structural members to act as latent defense to protect dwellings and occupants.

\section{Conclusions}

Instead of being classed and discarded as unwanted and difficult to dispose of, rice straw could become a viable commodity to be harvested. This paper summarizes work from ongoing study on the bearing capacity of straw bales. The test results demonstrate that straw bales are anisotropic, nonlinear, and highly deformable building material. Modulus of elasticity and bearing capacity of straw bale increased with increasing density. When straw bale blocks have a density being greater than $300 \mathrm{~kg} / \mathrm{m}^{3}$, the bearing capacity of straw bale blocks will be reliably desirable. When the density of straw bales is $337.80 \mathrm{~kg} / \mathrm{m}^{3}$, the bearing capacity of straw 
bales is 1.20 MPa. Existing baling machines can easily make the straw bale blocks to achieve the desired density, so that can be easily fabricated promoting the use of straw bales as building materials.

\section{Data Availability}

All the data used to support the findings of this study are included within the article.

\section{Conflicts of Interest}

The authors declare no conflicts of interest.

\section{Acknowledgments}

This research was supported by the Hainan Major Science and Technology Project (ZDKJ201803), National Natural Science Foundation of China (51968019 and 51368016), High-Level Talent Project of Hainan Basic and Applied Basic Research Plan (2019RC148 and 2019RC351), and "Nanhai Series" Yucai Program (no. 21 Document of Hainan Talent Office, 2019).

\section{References}

[1] C. Atkinson, "Building with straw bales-home grown home lecture notes," 2011, https://www.homegrownhome.co.uk/ homegrown homelecturenote.html.

[2] B. Hodge, Building Your Straw Bale home, Landlinks Press, Colling Wood, Australia, 2006.

[3] N. Corum, Building a Straw Bale House: The Red Feather Construction Handbook, Princeton Architectural Press, New York, NY, USA, 2005.

[4] C. Magwood, P. Mack, and T. Therrien, More Straw Bale Building-A Complete Guide to Designing and Building with Straw, New Society Publishers, Gabriola, Canada, 2005.

[5] S. Yetgin, Ö. Cavdar, and A. Cavdar, "The affects of the fiber contents on the mechanic properties of the adobes," Construction and Building Materials, vol. 22, pp. 222-227, 2008.

[6] A. Taha, W. Hansjorg, G. Heiko, B. Franz Josef, and W. Wei, "The influence of natural reinforcement fibres on insulation values of earth plaster for straw bale buildings," Materials and Design, vol. 31, pp. 4676-4685, 2010.

[7] A. Chel and G. N. Tiwari, "Thermal performance and embodied energy analysia of a passive house-case study of vault roof mud-house in India," Applied Energy, vol. 86, pp. 1956-1969, 2009.

[8] A. Thomson and P. Walker, "Durability characteristics of straw bales in building envelopes," Construction and Building Materials, vol. 68, pp. 135-141, 2014.

[9] M. J. O’Dogherty, J. A. Huber, J. Dyson, and C. J. Marshall, “A study of the physical and mechanical properties of wheat straw," Journal of Agricultural Engineering Research, vol. 62, pp. 133-142, 1995.

[10] S. P. Vardy, "Structural behavior of plastered straw bale assembles under concentric and eccentric loading," Ph.D. thesis, Queen's University, Kingston, Canada, 2009.

[11] S. Vardy and C. MacDougall, "Concentric and eccentric compression experiments of plastered straw bale assemblies," Journal of Structural Engineering, vol. 139, pp. 448-461, 2013.

[12] M. Palermo, L. M. Gil-Martin, E. Hernandez-Montes, and M. Aschheim, "Refined compression field theory for plastered straw bale walls," Construction and Building Materials, vol. 58, pp. 101-110, 2014.

[13] A. Taha, H. Georg, and W. Wu, "Performance of straw bale wall: a case of study," Energy and Buildings, vol. 43, pp. 1960-1967, 2011.

[14] B.-A. Ghailene, "Straw bales and straw bale wall systems," Master's thesis, University of Arizona, Tucson, Arizona, 1993.

[15] Liukun, E. Jiang, and J. Duan, Research on Bearing Capacity of Straw Bale, Chinese Society of Agricultural Engineering, Beijing, China, 2005.

[16] Y. J. Kim, A. Reberg, and M. Hossain, "Bio-building materials for load-bearing applications: conceptual development of reinforced plastered straw bale composite sandwich walls," Journal of Performance of Constructed Facilities, vol. 26, pp. 38-45, 2012.

[17] C. Magwood, P. Mack, and T. Therrien, More Straw Bale Building, New Society Publishers, Gabriola Island, Canada, 2005.

[18] S. Goodhew, R. Griffiths, and W. Tom, "An investigation of the moisture content in the wall of a straw-bale building," Building and Environment, vol. 39, pp. 1443-1451, 2004. 